\title{
Karst development of an evaporitic system and its hydrogeological implications inferred from GIS-based analysis and tracing techniques
}

\author{
José M. Gil-Márquez*, Juan A. Barberá, Matías Mudarra, Bartolomé Andreo, \\ Jorge Prieto-Mera, Damián Sánchez, L. David Rizo-Decelis, Manuel Argamasilla, \\ José M. Nieto, and Beatriz de la Torre \\ Department of Geology and Center of Hydrogeology, Faculty of Science, University of Málaga, Málaga, E-29071, Spain
}

\begin{abstract}
The geomorphological characteristics and hydrogeological functioning of a geologically heterogeneous evaporitic karst plateau in Southern Spain were studied. Land surface information (LiDAR data) was used to analyze the shape and distribution of closed depressions. An artificial tracer test and monitoring of the natural responses of the main spring have allowed to infer the karstic development of the studied system. Three dyes were injected in selected swallow holes to trace the main groundwater flowpaths and to estimate the dimension of the conduit network. Discharge, electrical conductivity and temperature were monitored in the groundwater that drains the evaporitic plateau during an individual and intense recharge pulse. Tracing techniques were adapted to high salinity environments by using specific calibration standards $(\mathrm{NaCl}+$ dye). The hydrological connection detected between two of the swallow holes and the outlet, and the deduced orientation pattern for closed areas, would suggest that the karst evolution (internal and external) is related to fault orientation. The rapid tracer detection (16-20 h) and high estimated maximum flow velocities $(125-192 \mathrm{~m} / \mathrm{h})$, together with the fast impulsional response of the controlled physicalchemical parameters in spring waters $(\sim 15-16 \mathrm{~h})$ demonstrate the existence of quick flows under recharge conditions with well-defined system drainage, indicating a high degree of internal karstification (estimated master conduit diameter $\sim 1.5 \mathrm{~m}$ ). However, flooding of the depressions feeding swallow holes and analysis of the spring response times from natural and artificial tracers point to a restriction of the system's drainage, most likely due to the constrained morphology of the karst conduits. This results in sustained recharge periods and delayed spring responses of some parameters, highlighting the relevant role of concentrated recharge in the hydrogeological behavior of the studied evaporitic karst.
\end{abstract}

Keywords: evaporitic karst, tracer experiments, brine spring, closed depression detection, southern Spain Received 25 January 2017; Revised 30 May 2017; Accepted 30 May 2017

Citation: Gil-Márquez J.M., Barberá J.A., Mudarra M., Andreo B., Prieto-Mera J., Sánchez D., RizoDecelis L.D., Argamasilla M., Nieto J.M. and de la Torre B., 2017. Karst development of an evaporitic system and its hydrogeological implications inferred from GIS-based analysis and tracing techniques. International Journal of Speleology, 46 (2), 219-235. Tampa, FL (USA) ISSN 0392-6672 https://doi.org/10.5038/1827-806X.46.2.2115

\section{INTRODUCTION}

Karst terrains developed in both carbonate and evaporite rocks cover approximately $20 \%$ of the icefree continental surface (Ford \& Williams, 2007), holding water resources large enough to supply almost a quarter of the global population. Major research efforts traditionally aim to understand hydrologic and hydrogeological processes in carbonate media (White, 1988; EC, 1995; Ford \& Williams, 2007), and many techniques have been customized to that end (Goldscheider \& Drew, 2007). In contrast, less attention has been paid to investigations focused on evaporitic karst formations, particularly those hosted throughout the Mediterranean area (Klimchouk et al., 1996; Gutiérrez et al., 2008; Liguori et al., 2008; Parise et al., 2008). Such studies generally address speleogenetic and karstological issues (Johnson, 1997; Klimchouk \& Aksem, 2005; Gutiérrez et al., 2008), or natural and human-induced geo-hazards (Galve et al., 2009; Gutiérrez et al., 2014). Hydrogeological advances in evaporitic karst are scarce (PulidoBosch \& Calaforra, 1993; Klimchouk, 1996, GilMárquez et al., 2017a), so little is known about the 
functioning of such aquifers (Chiesi et al., 2010). Groundwater flowing through evaporitic karst is often of poor quality, owing to high mineralization. Despite their limited interest for the drinking water supply, evaporite aquifers are of great value in that they are often associated with wetland dynamics (Sánchez et al., 2009; Andreo et al., 2016) and may support cave environments and interesting surface landforms (Williams, 2008). Furthermore, sinkhole formation and land subsidence are favored by groundwater table variations, particularly in evaporitic settings (Fidelibus et al., 2011; Acero et al., 2015). Therefore, the hydrogeology of evaporitic karst terrains has relevant societal and environmental implications.

The high solubility of evaporite rocks promotes intense geomorphological development, resulting in distinctive exokarstic features (e.g., dolines, poljes, swallow holes, etc.) and endokarstic ones (e.g., shafts, caves, conduits, etc.) features (Forti, 2004). Hydrologically, evaporite karst develops both autogenic recharge (through dolines, poljes, sinkholes) and allogenic recharge, through swallow holes (Ford $\&$ Williams, 2007). The identification of infiltration features at the surface is useful for groundwater recharge assessment in karst systems (Andreo et al., 2008). In recent works, GIS-based specific methods (i.e., digital processing of elevation data) have been developed to detect characteristic landforms and define their geometry (Siart et al., 2009; Anders et al., 2011). Additionally, Laser Imaging Detection and Ranging (LiDAR) airborne systems can provide accurate altitudinal data that can be used to generate high resolution Digital Elevation Models (DEM), with a spatial resolution $<1 \mathrm{~m}$ (Zhou et al., 2004). DEMs created from LiDAR data have proven useful for the identification of karst depressions in diverse evaporite media (Mudarra et al., 2016; Yechieli et al., 2016).

Like exokarstic landforms, endokarst features play a significant role in the functioning of evaporitic systems. One of the most reliable methods for investigating underground karst forms is based on speleological surveys (Jeannin et al., 2007). Yet scarcely developed conduit systems and/or their difficult accessibility very often restrict exploration to a reduced proportion of the speleological network. Tracing techniques provide detailed information about the conduit organization and groundwater pathways, even in complex geological or topographic settings (Goldscheider et al., 2008). When tracer tests are combined with the continuous monitoring of spring natural responses, they provide broader insight into the global functioning of the hydrogeological system (Lauber \& Goldscheider 2014; Mudarra et al., 2014). Published works on dye tracing in evaporite karst settings are scarce (Klimchouk, 1996; Birk et al., 2004; Chiesi et al., 2010), rarely describing specific techniques (Strasse et al., 2016) and possible limitations in detail. The latter issue is particularly relevant if halite is present in the bedrock, given the potential effect (positive or negative) of $\mathrm{NaCl}$ on dye tracer detection (Käss, 1998). Moreover, salinity can also contribute to sorption-desorption processes of organic fluorescent tracers on clays (Magal et al., 2008).
The so-called Chaotic Subbetic Complex (CSC) is an olistostromic unit (Vera \& Martín-Algarra, 2004) located by the southern border of the Guadalquivir River basin (Andalusia), in southern Spain. This melange is basically formed by clays and evaporite rocks (containing gypsum, anhydrite, and halite), as well as other blocks of diverse lithological nature (Perez-López \& Sanz de Galdeano, 1994). The rocks forming the CSC are highly folded and brecciated as a result of the large displacement and gravitational loading that they underwent during the Miocene age (Vera \& Martín-Algarra, 2004). Karst development within the CSC is most frequent on extensive exposures of gypsum, where numerous karst depressions develop, many of them hosting wetlands of high environmental value (Rodríguez-Rodríguez et al., 2010; Andreo et al., 2016). Endokarst features are likewise common within the CSC, and several caves have been surveyed: Cueva del Agua in Archidona, province of Malaga (Durán \& Burillo, 1985); Sima del Aguila, in Antequera, also in Málaga (Calaforra \& Pulido-Bosch, 1999); and Cueva del Yeso in Baena, province of Cordoba (González Ríos et al., 1994). The length of the explored passages ranges from $300 \mathrm{~m}$, in Cueva del Agua, to nearly 2,000 m in Cueva del Yeso, while the differences in height are from a few meters in Cueva del Agua (galleries practically horizontal) to more than $100 \mathrm{~m}$ in Sima del Aguila. With some exceptions, the typical conduit systems in this geological unit appear to be poorly developed and inaccessible, though having considerable length. Surface karst depressions are often drained by swallow holes, which govern the recharge response, and, the speleogenetic network therefore has great implications for the hydrogeological functioning of the CSC (Andreo et al., 2016).

Recent studies (Andreo et al., 2016; Gil-Márquez et al., 2017a) focused on the hydrogeological functioning of the CSC, have led to valuable knowledge about groundwater flow dynamics within this olistrostromic unit. A hydrogeological conceptual model, inspired on the Gravity-Driven Regional Groundwater Flow Model (Tóth, 1963, 1970), was proposed by Andreo et al. (2016) and adapted to the geological particularities of the CSC. This conceptualization consists of a hierarchized system including groundwater flowpaths of different lengths and residence times within the aquifer, from shallow local flows to deep regional ascending flows. The massive presence of clays in the bedrock determines the aquitard functioning of the CSC, where groundwater usually moves through a diffuse flow system. However, where evaporite rock formations are largely present, the water flow is also organized by karst conduits, which enhance the hydrogeological heterogeneity of the CSC.

The aim of this work is to obtain a deeper insight into the geomorphological and speleological characteristics of an evaporitic plateau within the CSC, exemplified in the Jarales Area (S Spain; Fig. 1), and assess their influence on the hydrogeological functioning of a geologically and hydrogeologically heterogeneous karst system. In addition, a better comprehension about the groundwater flow organization within 


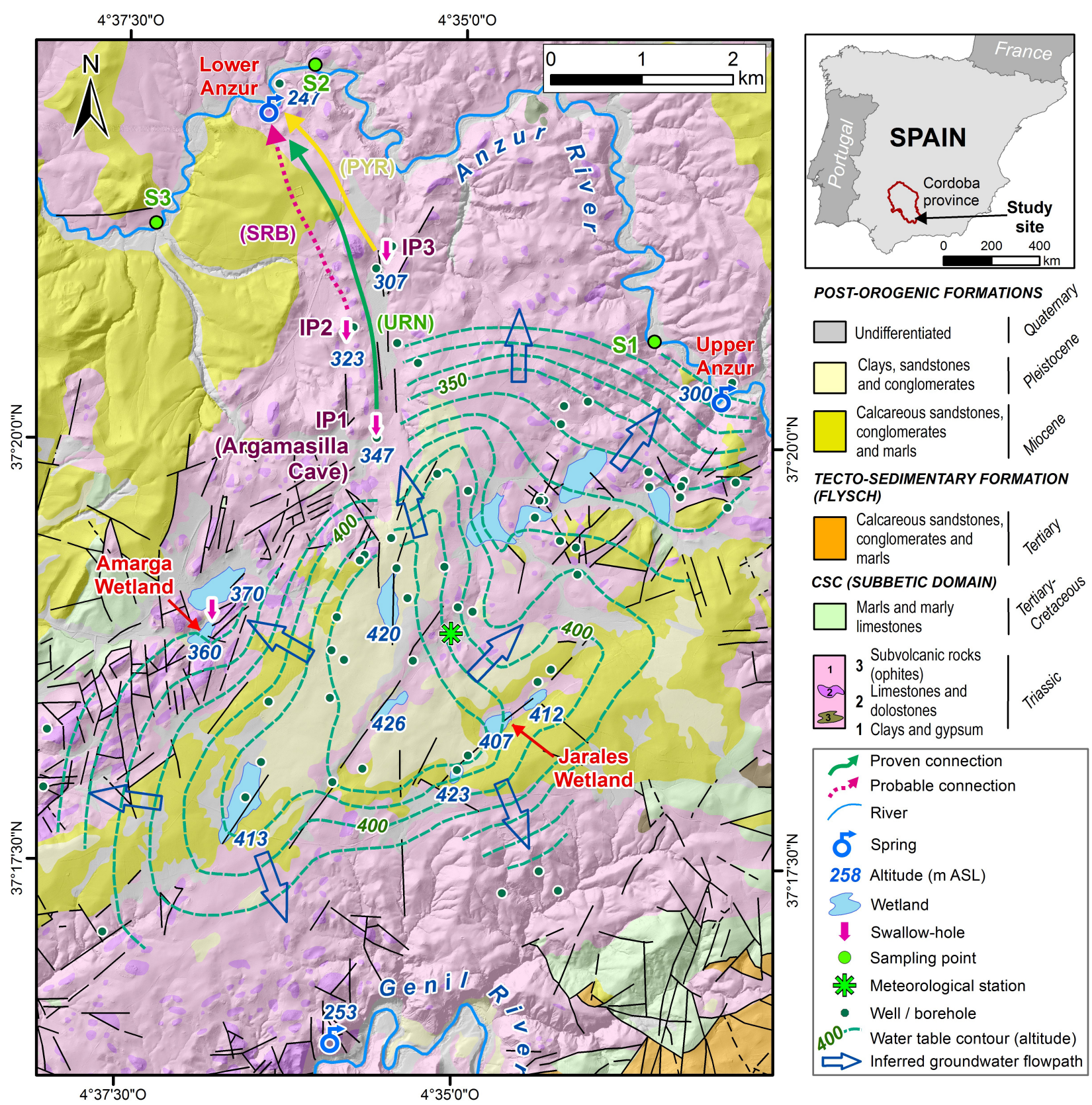

Fig. 1. Geographic location and geological-hydrogeological sketch of the Jarales area (Cordoba province, S Spain). Modified from Martín-Serrano (1986) and Divar et al. (1988). Hydrogeological connections deduced from the multi-tracer test results (PYR: pyranine, SRB: sulforhodamine B, URN: uranine) and groundwater table contours, (Andreo et al., 2016), are also displayed.

the evaporite karst is pursued. Several methods were jointly applied to analyze the structural implications of exo- and endokarst features on system hydrodynamics. Digital high resolution elevation data from Airborne LiDAR were used to characterize the shape and distribution of exokarst landforms, some of them containing functional swallow holes. A multiple-injection tracer test was performed and physical-chemical parameters (discharge, electrical conductivity - EC - and water temperature) of the main spring draining the CSC outcrops were monitored during an individual and intense recharge pulse. Dye tracing in evaporitic settings can be challenging because of saline water and high sediment loads. Hence, the integrated knowledge obtained from different approaches might open new research perspectives allowing for a better characterization of evaporitic karst systems and, consequently, reliable management of their geological and hydrological heritage.

\section{SITE DESCRIPTION}

\section{Location, climate and geology}

The Jarales area (Fig. 1) is an $80 \mathrm{~km}^{2}$ evaporitic karst plateau located in the southern part of Cordoba province (Andalusia, Spain), between the Genil River (to the south) and its tributary, the Anzur (to the north). Land use is predominantly extensive olive orchards (Fig. 2A), both rain-fed and irrigated. The prevailing climate is temperate Mediterranean, with a marked seasonal pattern in the annual rainfall distribution, which occurs mainly in autumn and winter (very often in a torrential way). The mean historic annual rainfall in the Jarales area is $412 \mathrm{~mm}$, and air temperature is $18^{\circ} \mathrm{C}$ (CMA, 2005).

The main lithologies cropping out in the Jarales area belong to the CSC, the olistostromic geological unit that occupies the northern sector of the socalled Subbetic Domain in the Betic Cordillera. This megabreccia comprises Triassic (Keuper) multi-colored 
clays and evaporitic rocks (gypsum, anhydrite and halite) as well as blocks of diverse age and lithology: Triassic and Jurassic carbonates, Cretaceous marls, Miocene sandstones, etc. (Vera \& Martin-Algarra, 2004). Gypsum is commonly found both as massive rock minerals and as a polygenic breccia. Although halite is absent from the near surface because of its high solubility, its existence at depth has been inferred from brine springs draining the evaporitic system (Gil-Márquez et al., 2017b; Fig. 1). The CSC is highly deformed as a consequence of the gravitational displacement that they have undergone during the Alpine orogeny (Pérez-López \& Sánz de Galdeano, 1994). Therefore, the original stratigraphic relationships are seldom preserved.

\section{Geomorphology, hydrology and speleological exploration}

The test site is characterized by gentle hills with modest relief (Fig. 2A), a poorly defined drainage network and the presence of numerous endorheic areas (closed depressions). Karst-derived depressions often host wetlands of diverse size and variable hydroperiod (Figs. 1 \& 2B), resulting from hydraulic interactions with the water table. The most significant wetlands are Jarales (Fig. 2B) and Amarga (Fig. 1), which together with other ephemeral lakes, constitute a complex of wetlands at the central part of the evaporitic karst area. The altitude of the bottom of such karst features diminishes from the center of the plateau (410$430 \mathrm{~m}$ a.s.1.) towards its borders, reaching heights near $300 \mathrm{~m}$ a.s.1. towards the north, where they are aligned along a north-south direction (Andreo et al., 2016). In the northern sector, the endorheic areas are naturally drained through constricted swallow holes (Fig. 1), resulting in occasional flooding during wet periods (Fig. 2C). One of the swallow holes is wide enough to be explored and is the entrance to Argamasilla Cave (Figs. 1 \& 2D).

Argamasilla Cave has been known locally for a long time, but was only recently described in the literature (González-Ríos et al., 1994; CMA, 2005). The entrance to the cave was formerly used as a dump for agricultural wastes derived from olive oil production, which were later detected at the most significant discharge point (Lower Anzur Spring, $247 \mathrm{~m}$ a.s.1.; Figs. 1 \& 2E), indicating a connection between the two points (Mora, 2006). The cave has been explored for $30 \mathrm{~m}$ (Aljama-Martinez, 2016) and its main morphometric characteristics are described in Fig. 3. The entrance, $1 \mathrm{~m}$ high and $1.5 \mathrm{~m}$ wide, is located below a 3-m vertical wall, in a small depression excavated by sinking waters (Fig. 2D). The gallery is 1-1.5 m wide and starts with a $7 \mathrm{~m}$ gentle slope, followed by a sequence of short shafts (Fig. 3). After approximately $10 \mathrm{~m}$ of drop, an $8 \mathrm{~m}$ long half-flooded corridor extends, tracing several curves until reaching a sump (Figs. $3 \& 4 \mathrm{~A}$ ), which has impeded further explorations for the time being (Aljama-Martinez, 2016). No speleothems were found along the explored section of the cave.

Besides the direct infiltration of runoff into the swallow holes, recharge also takes place by diffuse infiltration of rainwater through gypsum and
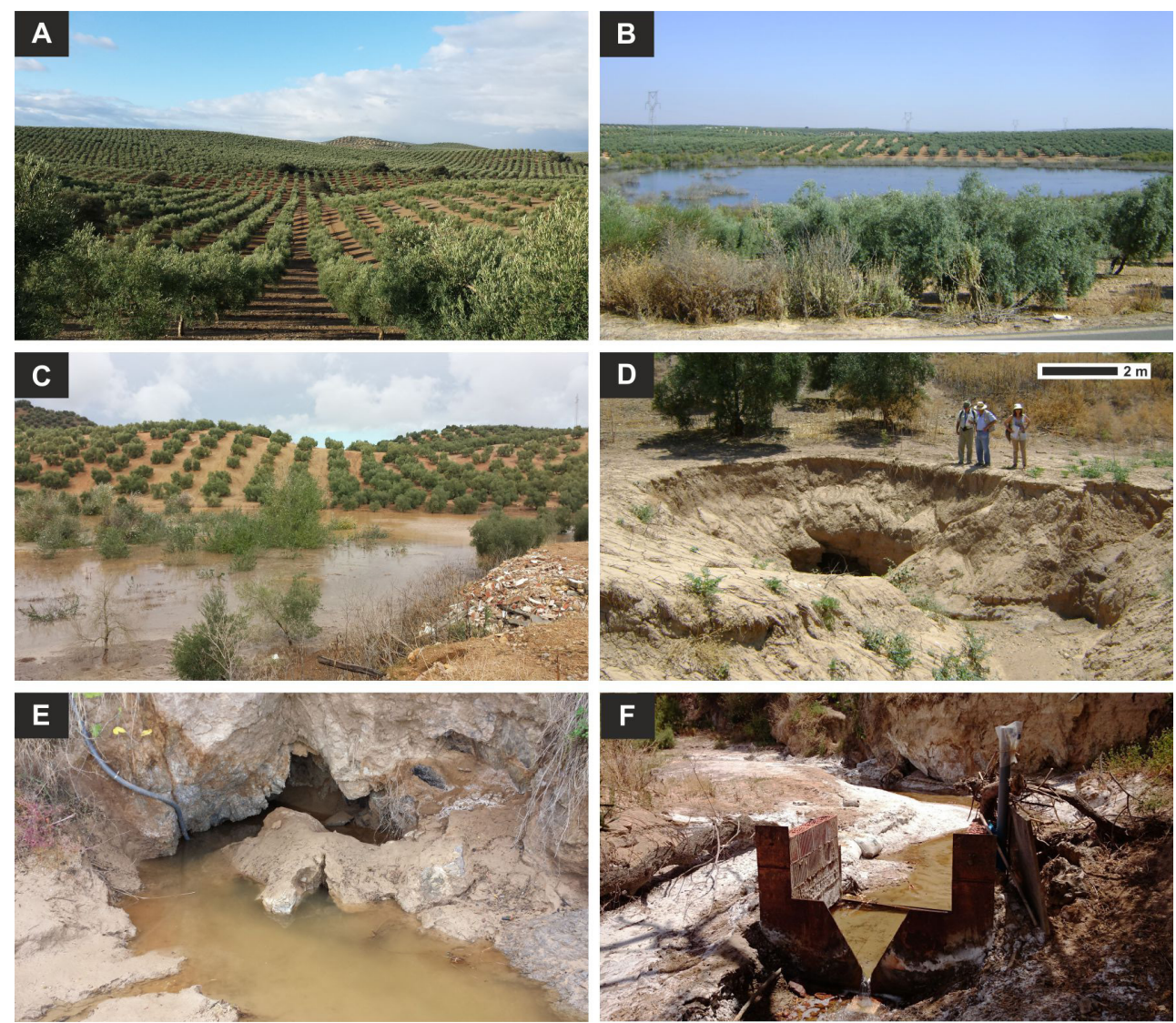

Fig. 2. A) Olive orchards, the prevailing landscape in Jarales area; B) Overview of the Jarales seasonal wetland (August, 2013); C) Flooding of the closed depression drained by Argamasilla swallow hole;

D) Entrance to Argamasilla swallow hole on Triassic clays connected with a gypsum cave (IP1);

E) Lower Anzur Spring; F) Gauging station equipped with water level logger. 


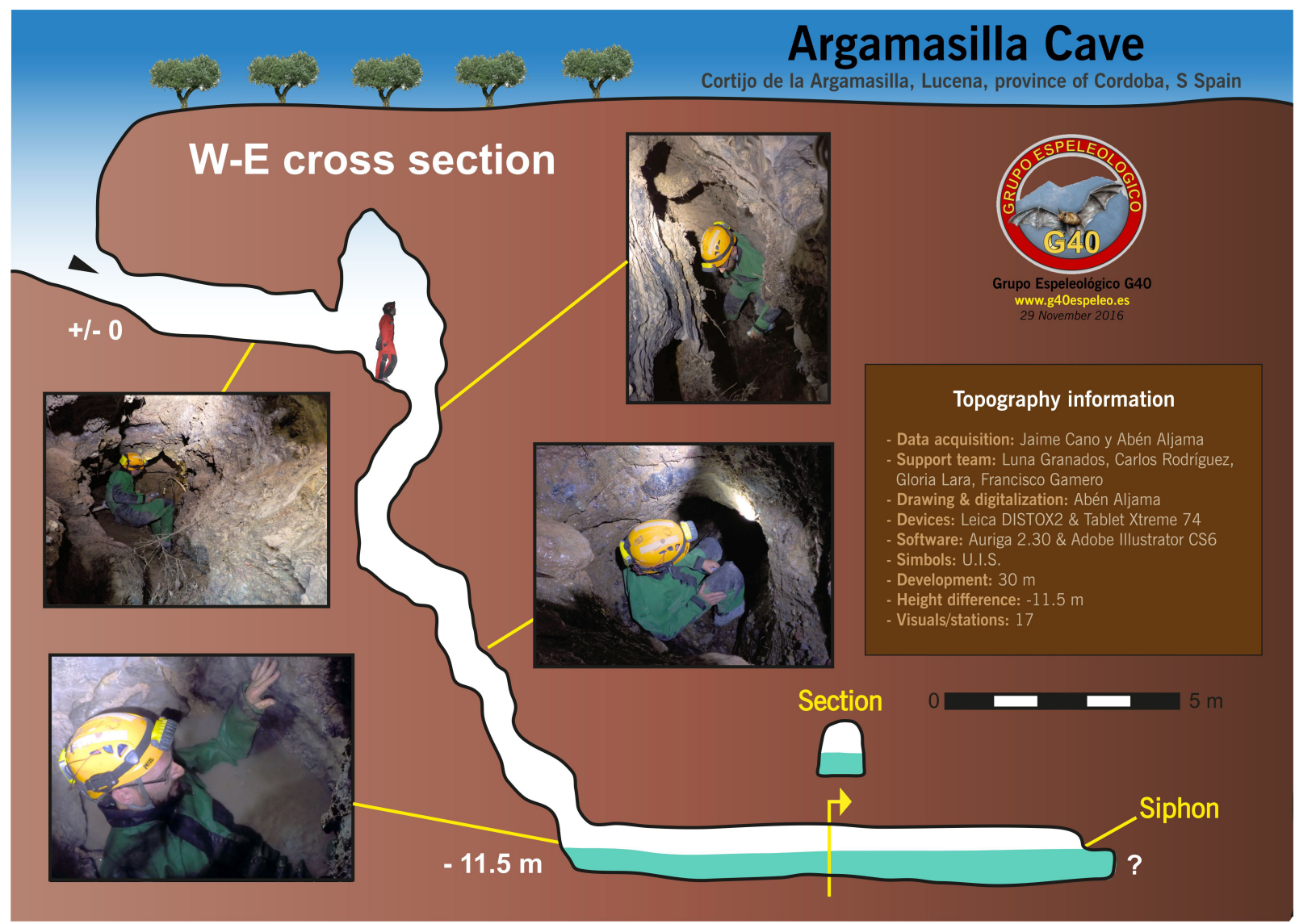

Fig. 3. Cross section of Argamasilla Cave including pictures taken at different sections. Modified from Aljama-Martínez (2016).

calcareous outcrops, and probably through the bottom of wetlands and other closed depressions as well (Gil-Márquez et al., 2017b). Given the general aquitard behavior of the CSC, groundwater predominantly flows within a diffuse-type system. Flowpaths are radially divergent, from the higher altitudes of the plateau to its borders (Fig. 1). Natural discharge mainly occurs northwards, via springs located along the Anzur River bed. Outflow towards the Genil River completes the groundwater system drainage (Andreo et al., 2016). Despite the fact that regional groundwater discharge is associated with a diffuse flow system, having long residence times, the springs show rapid natural responses to recharge events that are typical of karst conduits. This karst behavior is even more remarkable at the Lower Anzur spring, where high discharge variability and dilution effects on water mineralization have been registered (Gil-Márquez et al., 2017b).

\section{METHODS}

\section{Automatic detection of karst depressions}

For the automatic identification of negative relief karst landforms, GIS-based approaches were applied, focused on the data processing of high resolution digital elevation models (DEM). The raster dataset used in this work was created with a $0.5-\mathrm{m}$ resolution, from LiDAR airborne point cloud information (PNOA, 2016), with a spatial density of 0.5 points $/ m$, and an altimetric accuracy of $0.2 \mathrm{~m}$. Using the Pit Removal tool of ArcMap $^{\mathrm{TM}}$ software (ESRI), a new DEM was created, in which all closed depressions were filled up to their overflowing thresholds. Then, the original
DEM was subtracted from the newly generated raster, resulting in a modified DEM that shows the location and morphology (including depth) of all depressions in the selected area (Siart et al., 2009; Anders et al., 2011). Final results were validated for those depressions bigger than $500 \mathrm{~m}^{2}$ by field observations and areal image checking. This method has provided satisfactory results in other karst areas in S Spain, both in carbonate (Pardo-Igúquiza et al., 2013) and evaporitic media (Mudarra et al., 2016). Finally, the orientation of the main axis of the closed depressions was calculated and classified using GIS tools.

\section{Multi-injection tracer test setting and other field methods}

Three active karst swallow holes in the northern sector of the pilot site were selected (Fig. 1): IP1, coinciding with the entrance of Argamasilla Cave (347 $\mathrm{m}$ a.s.1.); IP2, at the bottom of a small doline (323 $\mathrm{m}$ a.s.1.); and IP3 (307 $\mathrm{m}$ a.s.1.), the main drainage point of a large polje (Fig. 1). Tracers were injected during a high intensity rainfall event between 1 and 2 November 2015, which permitted the direct infiltration of generated runoff through the swallow holes. The selected fluorescent dyes were uranine (URN; CAS RN: 518-47-8), pyranine (PYR; CAS RN: 6358-69-6) and sulforhodamine B (SRB; CAS RN: 3520-42-1). A total mass of $1 \mathrm{~kg}$ of URN was released into IP1 at 9 p.m. (Fig. 5A), $0.98 \mathrm{~kg}$ of PYR was injected into IP3 at 9.45 p.m., and $1.5 \mathrm{~kg}$ of SRB was introduced into IP2 at 11.40 p.m. (Fig. 5B). The estimated sinking flow into IP2 and IP3 amounted to $15 \mathrm{l} / \mathrm{s}$ in both cases. On the other hand, infiltration flow into IP1 progressively increased, from 1-2 1/s to approximately 200 1/s. EC 

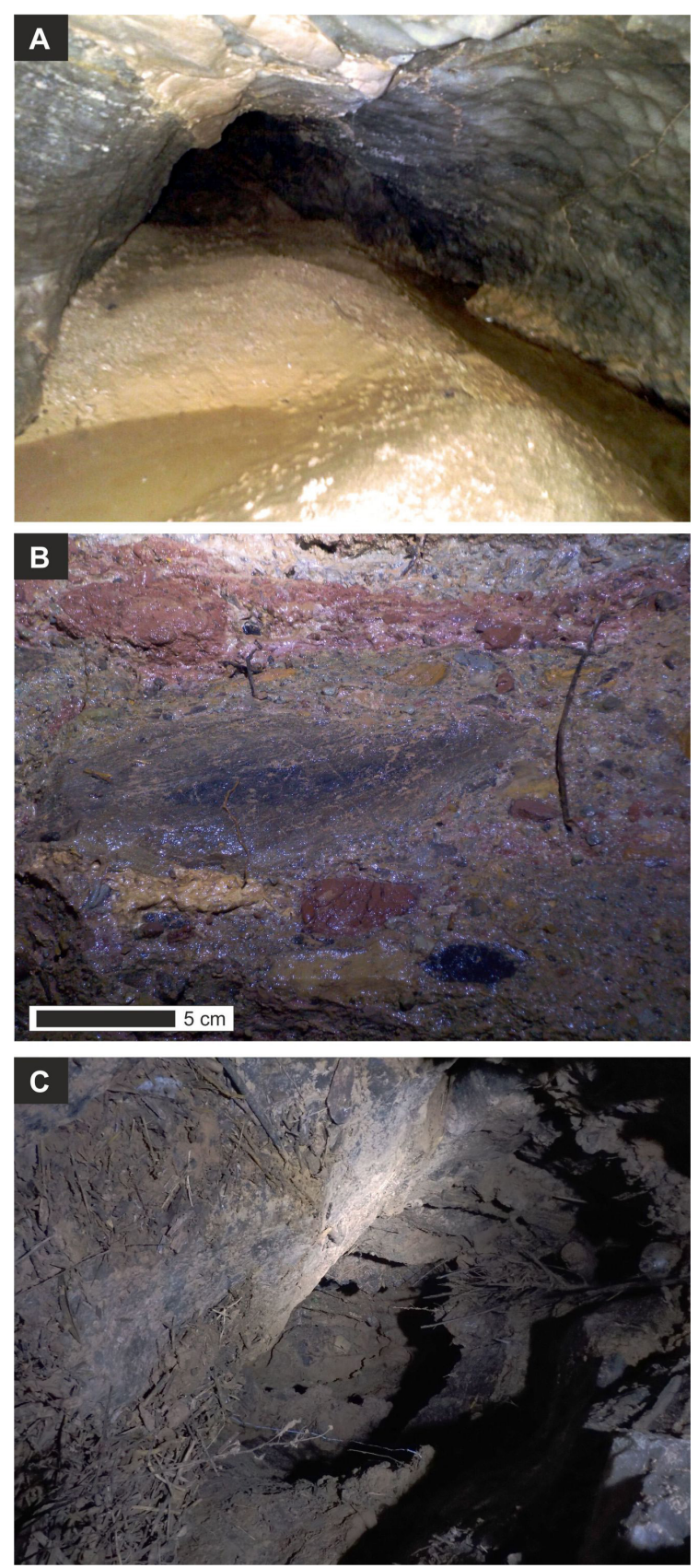

Fig. 4. A) Half-flooded lower gallery of Argamasilla cave, partially filled by silty-clayey sediments. The conduit walls are constituted by massive gypsum; B) Detail of a polygenic-breccia inside the cave; C) Accumulation of plants and organic matter within the main gallery (Photos by Abén Aljama Martínez). and temperature of recharge waters were in the range of $1.2-1.5 \mathrm{mS} / \mathrm{cm}$ and $12.8-14.0^{\circ} \mathrm{C}$, respectively. At the end of the rainfall event, the drainage capacity of all swallow holes was exceeded, leading to flooding of the endorheic areas that they drain (Fig. 2D). Flooding conditions persisted for several days, and the swallow holes were active until 7 November 2016.

From 1 November to 2 December 2015, 129 water samples were collected from the main discharge points (Lower Anzur and Upper Anzur springs; Fig. 1 ), and from surface water points of the Anzur River (S1, S2 and S3; Fig. 1). During the first three days, the sampling routine was performed hourly at Lower Anzur spring, and twice a day at the other control points. Sampling periodicity was progressively decreased, ending with once a week. All water samples were collected in $75 \mathrm{ml}$ amber glass bottles and were stored in the laboratory of the Center of Hydrogeology of the University of Malaga (CEHIUMA), isolated from light to prevent photodegradation of the dye substances. Prior to fluorescence determination, the samples were settled to separate the liquid phase from the suspended solids.

Discharge of the Lower Anzur spring was simultaneously observed at a gauging station equipped with a $60^{\circ} \mathrm{V}$-notch weir (Fig. 2F), a water level stage, and a pressure-depth (water level) probe (ODYSSEY $^{\mathrm{TM}}$ depth/temperature logger) with 0.8 $\mathrm{mm}$ accuracy. The hourly water level variations were subsequently transformed into spring discharge data by applying the corresponding rating curve, whose accuracy was checked from single discharge flow measurements (OTT ${ }^{\mathrm{TM}} \mathrm{C} 2$ flow meter) and water level readings. In addition, electrical conductivity (EC) and temperature of the Lower Anzur spring waters were measured hourly using a conductivity/temperature meter with data logger function $\left(\mathrm{WTW}^{\mathrm{TM}}\right.$ Cond 340i) installed in the outlet. To check the accuracy of the recording physical-chemical parameters, discrete EC and temperature measurements were also performed $\left(\mathrm{WTW}^{\mathrm{TM}}\right.$ Cond 3310) with the same periodicity as sample collection. Rainfall data were recorded hourly by an automatic weather station located at $390 \mathrm{~m}$ a.s.1., $1 \mathrm{~km} \mathrm{NE}$ from the Jarales wetland (Fig. 1).

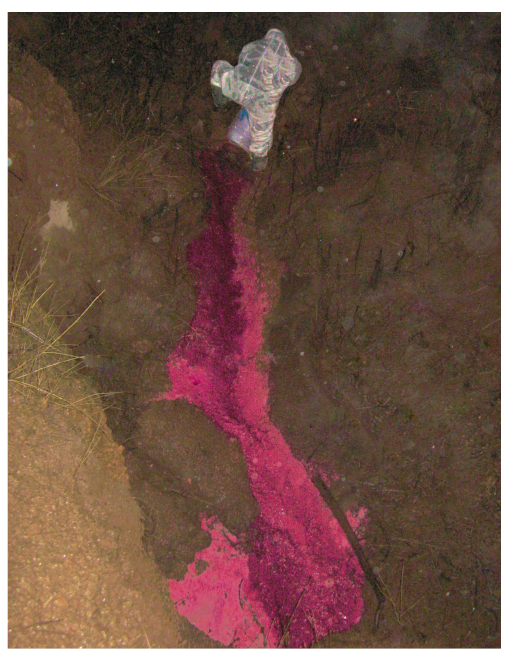

Fig. 5. Left: Uranine injection into the Argamasilla cave swallow-hole (IP1); Right: Sulforhodamine B injection into the IP2. 
Analytical determination of tracer concentration and conduit volume estimation

The analysis of fluorescent tracers was performed in the laboratory within $48 \mathrm{~h}$ after sampling, by means of the synchronous scan method, using a luminescence spectrometer PERKIN ELMER ${ }^{\mathrm{TM}}$ LS-55. Since URN and PYR show similar wavelength spectra for maximum excitation values, the simultaneous detection of both substances in a water sample required the analytical separation of the tracer signals. For that objective, the software PeakFit ${ }^{\mathrm{TM}}$ was used to remove the base line (background levels) in the raw curves, while for its decomposition in independent tracer peaks (one per each dye) the Gaussian deconvolution method was applied (Alexander, 2005). The coefficient of the determination $\left(R^{2}\right)$ of the obtained concentration curves was higher than 0.99 .

Calibration entailed serial dilution of a master dissolution of each tracer. Due to the effect of salinity on the tracer concentration (Käss, 1998; Magal et al., 2008), each solution was prepared using salt water with a $\mathrm{NaCl}$ concentration of $150 \mathrm{~g} / 1$. This value is close to the mean $\mathrm{NaCl}$ content of Lower Anzur spring waters (Gil-Márquez et al., 2017b). No additional calibration curves were made for distinct salinity values, as it was empirically checked (Fig. 6) that the observed salinity variations, in the range of $110-160 \mathrm{~g} / 1$ of $\mathrm{NaCl}$, had a minor influence on tracer detection.

The water volume drained by the Lower Anzur Spring was quantified by integrating the continuous discharge record during the study period. The volume of the whole karst network was estimated as the volume drained by the outlet from the centroid of the recharge event to the peak discharge time (Luhmann et al., 2012). To account for the water volume of single conduits that connect injection points with sampling sites, various reference times in BTCs were considered (Vojtechovska et al., 2010). Mean conduit diameters were estimated from conduit sections, which were previously calculated by dividing the conduit volume by its length (after applying a sinuosity factor of 1.5).

\section{RESULTS}

\section{GIS-based automatic detection of evaporitic-karst depressions}

Figure 7 shows the results derived from the automatic identification of closed depressions in the Jarales area. The GIS-based approach revealed depressions from meters to hundreds of meters in diameter, and made it possible to analyze their morphometric properties below the overflow thresholds. It should be noted that the Pit Removal tool fills the closed depressions identified in the original DEM up to their threshold, and therefore the resulting DEM is useful to point out the endorheic areas but not for delineating their whole catchment area. A total of 64 closed depressions larger than $500 \mathrm{~m}^{2}$ were recognized by the GIS algorithm, 53 of which were confirmed by field checks. The other 11 areas correspond to anthropogenic, generally small (<0.5 ha) structures (e.g., irrigation pools, quarries, etc.). Towards the east, some ephemeral ponds delineated as wetland areas in Figure 7 were not recognized by the DEM geoprocessing. Later validations indicate that those areas were artificially drained by ditches, impeding their automatic identification.

In general terms, the depressions located at the central part and to the SW of the evaporitic plateau are shallower than those situated towards the $\mathrm{N}$, NW and SE (Fig. 7). In the northern sector, where endorheic areas are drained by swallow holes, the GIS-based algorithm provides detailed information on the morphometric properties of the above features (Fig. 7A-C). For example, it is possible to observe the welldeveloped drainage network existing in the endorheic area drained by Argamasilla swallow-hole (Fig. 7D).

Figure 7 also displays the spatial distribution and direction of the predominant set of fractures affecting the CSC materials and other lithologies in the Jarales area. The trace of mapped faults in this area shows three predominant directions (Fig. 7): NE-SW, NW-SE and N-S. Preliminary results show that the main axes of $70 \%$ of the largest identified closed depressions ( $>0.5 \mathrm{ha}$ ) are aligned either in $\mathrm{N}-\mathrm{S}$ or NE-SW orientations (Fig. 7). This percentage reaches $85 \%$ if the closed depressions with NW-SE axes are also considered.

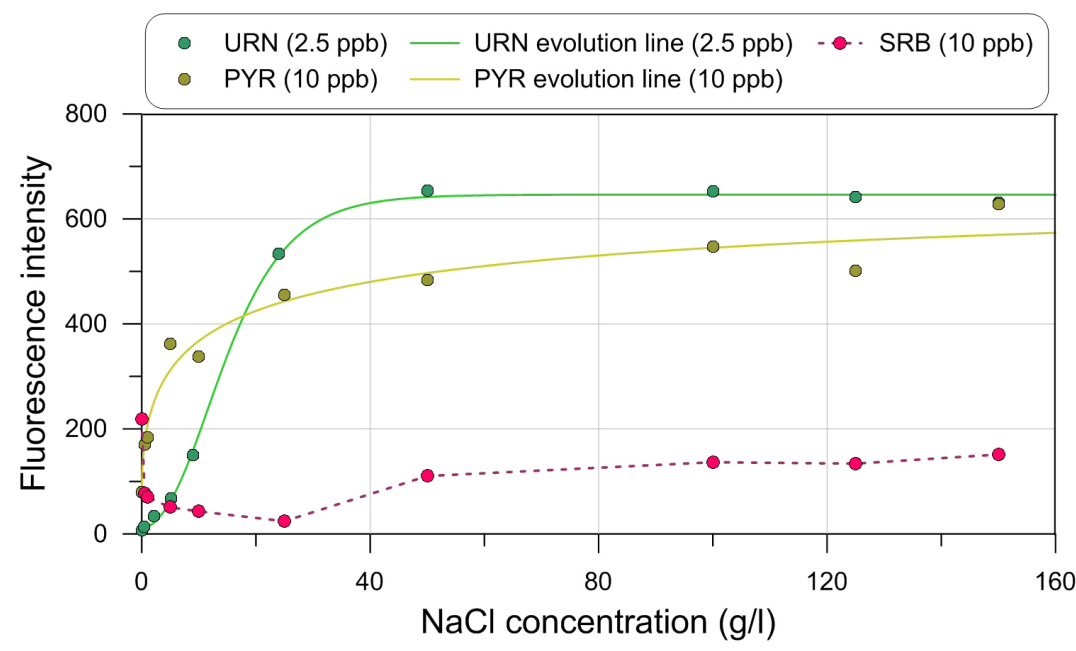

Fig. 6. Variation of fluorescence intensity signal as function of salinity for uranine, pyranine and sulforhodamine $B$ at $2.5,10$ and $10 \mathrm{ppb}$ concentration, respectively.

\section{Tracer test results and analysis of tracer breakthrough-curves (BTCs)}

A total rainfall of $67 \mathrm{~mm}$ accumulated during the month before the performance of the tracing experiment, promoting the activation of the system drainage in the Lower Anzur Spring (Fig. 8). During the day of the injection, an intense rainfall event (44 $\mathrm{mm}$ in 6 hours) occurred, provoking a rapid generation of runoff and its flow into the swallow holes. Since no significant rainfall was recorded in the following weeks, the tracer test was carried out coinciding with a large unitary recharge event (Fig. 8), a few weeks after a smaller one, which led to the activation of the whole karst drainage network. 


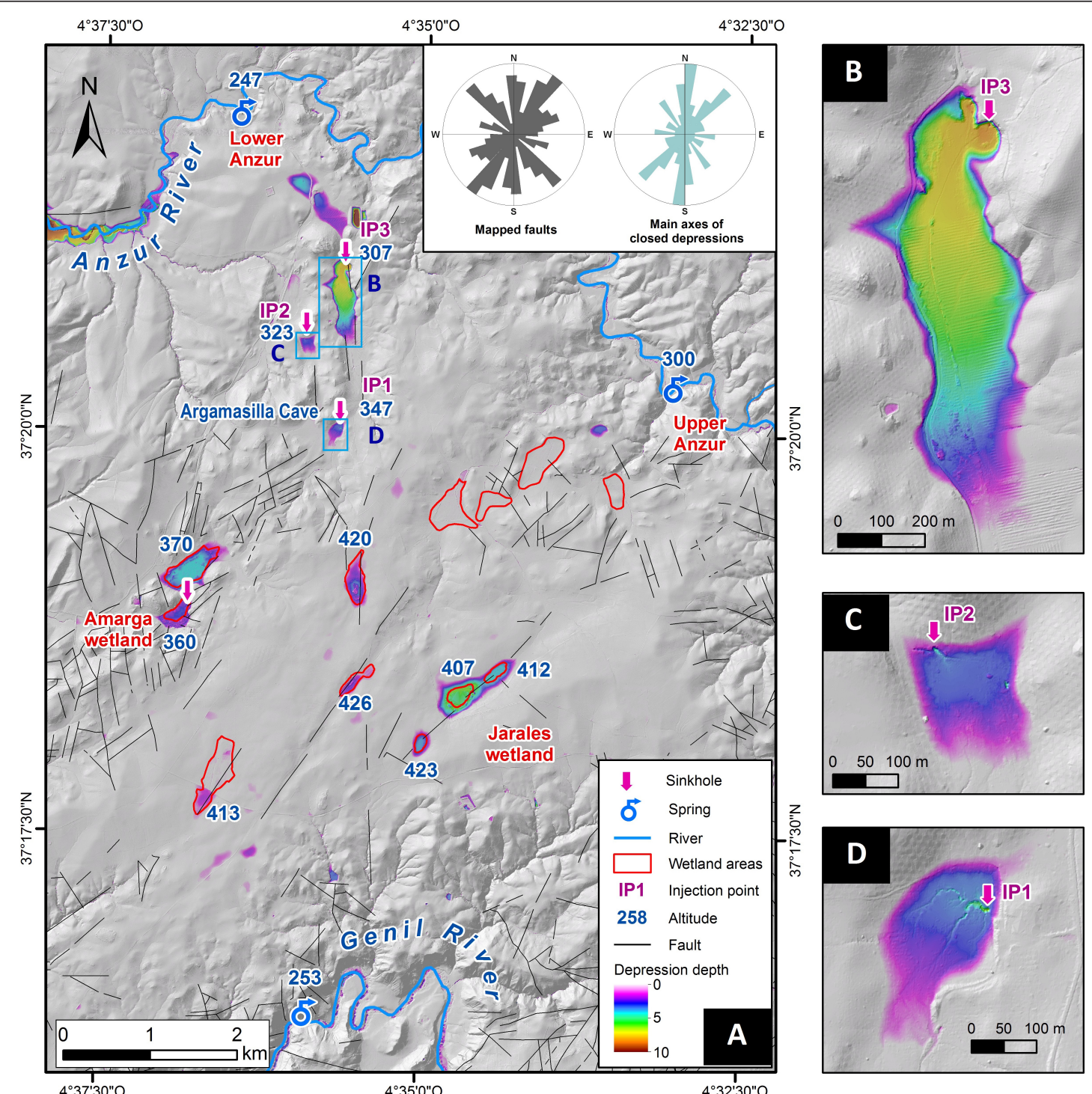

Fig. 7. Results of the automatic detection analysis of depressed landforms. Wetland areas previously identified by CMA (2005) are outlined in red. Rose diagrams of the mapped faults and the main axes of the largest closed depressions are presented. Detailed geoprocessed images of depressions hosting swallow holes are displayed in the right column.

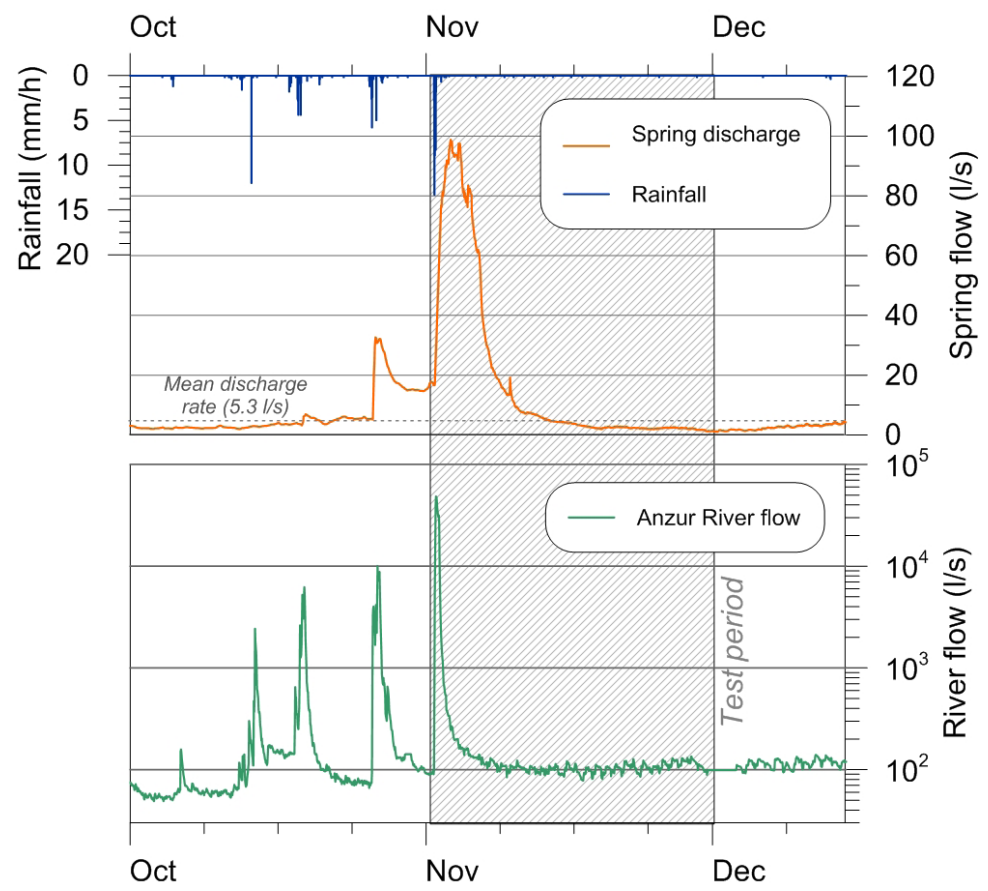

Fig. 8. Hydrographs of Lower Anzur Spring and Anzur River at point S2 from 1 October to 15 December 2015. Mean spring discharge (March 2014 to August 2016 period) and rainfall distribution are also shown. 
Among the three injected tracers, only URN and PYR were detected at the Lower Anzur Spring water during the control period. They also appeared at sampling point S3 of surface water, located in the river, downstream from the main outlet (Fig. 1). SRB was not detected during the test, nor throughout the following year. The analytical results of the tracer test obtained for the Lower Anzur Spring are summarized in Table 1. PYR was first detected at the outlet, 16 hours after the injection and $17 \mathrm{~h}$ after the gravity center of the rainfall event (10 p.m., 1 November), the latter understood as the moment in which half of the total rain has fallen. Maximum tracer concentration reached $9 \mu \mathrm{g} / 1$, after 26 hours (Tab. 1 \& Fig. 9). The fastest groundwater flow velocity calculated was $125 \mathrm{~m} / \mathrm{h}$, while the average (i.e., predominant) one was $78 \mathrm{~m} / \mathrm{h}$. URN appeared $4 \mathrm{~h}$ later than PYR, with a more diluted and delayed peak concentration $(0.6 \mu \mathrm{g} / 1$ after $54 \mathrm{~h}$; Tab. 1 \& Fig. 9). As the traced hydrogeological connection is almost double in length, the maximum flow velocity calculated for URN is $192 \mathrm{~m} / \mathrm{h}$, the average flow velocity (70 $\mathrm{m} / \mathrm{h})$ being slightly lower than that for PYR. Since a karst flow route is unlikely to be straight, any sinuosity would result in proportionately higher flow velocities. The recovery rates of both dyes were very low: 13\% (127.4 g) for PYR and 0.9\% (9 g) for URN.
PYR and URN BTCs show sharp rises in dye concentration, followed by slower decreases to an increased background level (Fig. 9). This observation is much more evident for PYR, reflecting a welldefined exponentially decreasing curve, while URN BTC is more elongated (Curtosis coefficient of 4.17, Tab. 1). In both cases, but particularly for URN, travel times and dispersion indicate a low mixing efficiency in the conduit flow and/or the existence of retardation processes.

PYR and URN were first detected at S3 on the third day after injections, coinciding with the highest spring discharge rate, and after the Anzur River flow peak passed (Fig. 8). The highest concentrations of PYR and URN in S3 waters were found to be substantially lower (Tab. 1) than those measured simultaneously at the Lower Anzur Spring, suggesting that there may have been a dilution of the dye drained by the Lower Anzur spring when mixing with the river waters. The recovery rates calculated for both tracers at S3 were much lower than that at the spring (Tab. 1) and even lower than that expected from a theoretical mixing between the river ( $\mathrm{S} 2$ gauging station) and the spring waters. Nevertheless, recovery rates calculated for the Lower Anzur River for the same period in which the dyes appeared at S3 (when the dilution influence was lesser) were $3.5 \%$ for PYR and $0.5 \%$ for URN. While these values are still higher than those calculated at

Table 1. Main hydraulic parameters deduced from the multi-tracer test. * Mean spring discharge refers to the study period (1 November to 2 December 2015).

\begin{tabular}{|c|c|c|c|c|}
\hline Injection Point & $\begin{array}{c}\text { IP1 } \\
\text { (Argamasilla Cave) }\end{array}$ & IP2 & IP3 & Unit \\
\hline Tracer & URA & SRB & PYR & \\
\hline Injected mass & 1 & 1.5 & 0.98 & $\mathrm{~kg}$ \\
\hline Altitude & 347 & 323 & 307 & m a.s.1. \\
\hline \multirow{2}{*}{ UTM coordinates } & 358,787 & 358,339 & 358,874 & \multirow{2}{*}{$\mathrm{m}$} \\
\hline & $4,133,703$ & $4,134,105$ & $4,134,963$ & \\
\hline \multicolumn{5}{|l|}{ Analytic results } \\
\hline Sampling Point & \multicolumn{4}{|c|}{ Lower Anzur spring } \\
\hline \multirow{2}{*}{ Discharge rate* } & Mean & Maximum & Minimum & \\
\hline & 17.9 & 98.9 & 1.2 & $1 / \mathrm{s}$ \\
\hline Distance from injection point & 3,800 & 2,700 & 2,000 & $\mathrm{~m}$ \\
\hline First detection time & 20 & $\mathrm{n} / \mathrm{d}$ & 16 & $\mathrm{~h}$ \\
\hline Time to peak concentration & 54 & $\mathrm{n} / \mathrm{d}$ & 26 & $\mathrm{~h}$ \\
\hline Peak concentration & 0.6 & $\mathrm{n} / \mathrm{d}$ & 9.0 & $\mu \mathrm{g} / 1$ \\
\hline Maximum flow velocity & 192 & - & 125 & $\mathrm{~m} / \mathrm{h}$ \\
\hline Maximum average flow velocity & 70 & - & 78 & $\mathrm{~m} / \mathrm{h}$ \\
\hline Recovery rate & 0.9 & - & 13 & $\%$ \\
\hline Skewness & 1.78 & - & 0.23 & \\
\hline Kurtosis & 4.17 & - & 1.05 & \\
\hline Sampling Point & \multicolumn{4}{|c|}{ S3 } \\
\hline \multirow{2}{*}{ River flow rate } & Mean & Maximum & Minimum & \\
\hline & 723 & 48,376 & 81 & $1 / \mathrm{s}$ \\
\hline Distance from injection point & 3,300 & 2,300 & 2,500 & $\mathrm{~m}$ \\
\hline First detection time & 64 & $\mathrm{n} / \mathrm{d}$ & 63 & $\mathrm{~h}$ \\
\hline Time to peak concentration & 64 & $\mathrm{n} / \mathrm{d}$ & 92 & $\mathrm{~h}$ \\
\hline Peak concentration & 0.04 & $\mathrm{n} / \mathrm{d}$ & 0.45 & $\mu g / 1$ \\
\hline Recovey rate & 0.2 & - & 1.9 & $\%$ \\
\hline
\end{tabular}




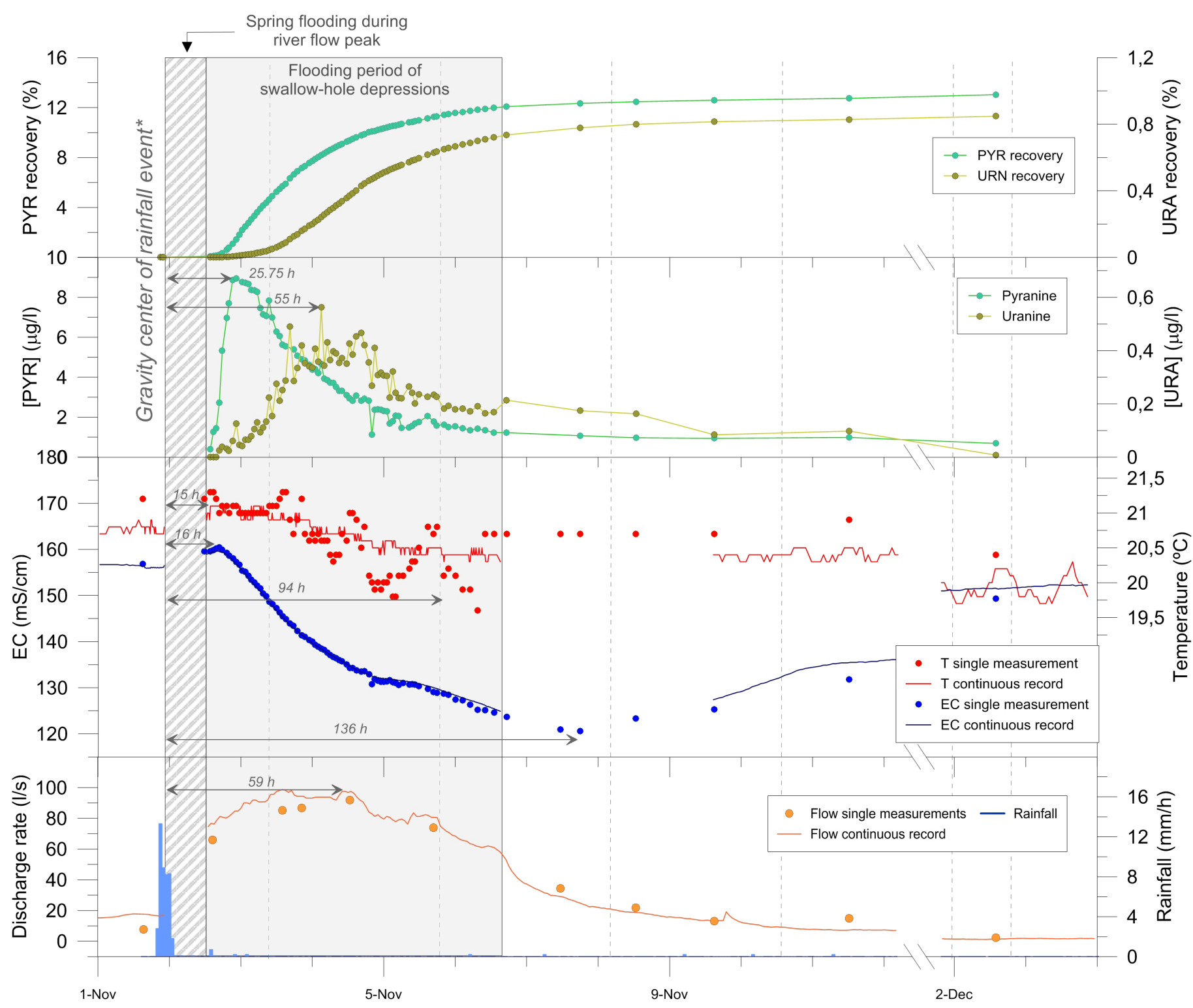

Fig. 9. Time series of spring flow, electrical conductivity, water temperature and tracer concentrations at the Lower Anzur Spring. Estimated response times and recovery rates are also displayed. It should be noted that $X$ axes are broken. $\left.{ }^{*}\right)$ Tracer response times are referred to the gravity center of the rainfall event, which for PYR differs from values in table 1, unlike URN times.

S3 (Tab. 1), they are more reasonable. The remaining difference could be due to a light degradation of the tracers, retention by sediments and vegetation, dilution caused by runoff from other creeks located between the outlet and S3, or to the minor sampling frequency of the river waters (2-3 times a day). Furthermore, there are some uncertainties related to tracer concentration determination at S3. Salinity of S3 waters during dye positive detection was in the range of 21-42 g/1, and the enhancement of fluorescence intensity was lower than that for the spring. This, together with the low concentrations of both dyes (particularly URN) and their simultaneous appearance, led to poorly defined peaks and, therefore, to less accurate separation of the tracer curves.

The conduit volumes calculated from the test results are displayed in Table 2. The estimation of the volume of the whole network was obtained from the delay between the recharge pulse centroid and the discharge rate peak. As this volume is referred to the whole karst network, whose entire length is unknown, no section sizing was possible. For each one of the traced connections, two times were considered: the delay between the injection and the concentration peak, and the dye mean transit time within the system. Regarding PYR, the estimation is lower for the first time, whereas in the case of URN both times were the same, and so were the corresponding volumes. Although the two PYR volumes are not very different, the peak time volume is chosen for discussion, as the mean transit time does not provide reliable data when the BTC curve has a high long-lasting tail (Käss, 1988). The conduit volumes estimated from URN velocities are not consistent with the smaller volume calculated for the whole network.

\section{Analysis of natural responses of the Lower Anzur Spring}

During the study period, a relatively quick flow variation in response to the main recharge event (from $16.9 \mathrm{l} / \mathrm{s}$ to $91.9 \mathrm{l} / \mathrm{s}$ ) was detected in the Lower Anzur Spring, with a time lag of 60 hours between the center of gravity of precipitation and the discharge peak in the spring (Fig. 9). This peak appears to coincide with the highest concentration of URN in the spring water, followed by three days of gentle decrease until $61 \mathrm{l} / \mathrm{s}$ 
Table 2. Times of reference in BTCs and estimated volumes and mean diameters of the master conduit.

\begin{tabular}{|l|c|c|c|}
\hline \multicolumn{1}{|c|}{ Time of reference (BTC) } & $\begin{array}{c}\text { Time period } \\
\text { (min) }\end{array}$ & $\begin{array}{c}\text { Estimated } \\
\text { volume (m) }\end{array}$ & $\begin{array}{c}\text { Mean conduit } \\
\text { diameter (m) }\end{array}$ \\
\hline Recharge centroid to peak discharge & 2,460 & 10,488 & - \\
\hline Injection time to URN peak (max) & 3,240 & 14,993 & 1.83 \\
\hline Injection time to PYR peak (max) & 1,485 & 5,263 & 1.49 \\
\hline URN mean transit time & 3,240 & 14,993 & 1.83 \\
\hline PYR mean transit time & 1,665 & 6,206 & 1.62 \\
\hline
\end{tabular}

(1 p.m., 6 November), and then by a sudden and faster fall in the spring hydrograph, which coincided with the end of the waterlogging period in swallow hole depressions. No data for the first $14 \mathrm{~h}$ after recharge is available (stripped area in Fig. 9) due to the increase in Anzur River flow that produced complete flooding of the spring area, which impeded a correct spring monitoring.

The impulsional response of the spring provoked an EC peak $(160.4 \mathrm{mS} / \mathrm{cm})$, with a 16 -hour timelag, followed by a delayed fall of water mineralization (dilution up to $120.6 \mathrm{mS} / \mathrm{cm}, 136 \mathrm{~h}$ after recharge peak) and a later slow recovery during the spring depletion (Fig. 9). Groundwater temperature in Lower Anzur Spring displays a similar pattern to that of the $\mathrm{EC}$, especially during the period in which depressions were flooded (Fig. 9). Thus, simultaneously to the EC peak, a quick rise of $0.5^{\circ} \mathrm{C}$ (from 20.6 to $21.1^{\circ} \mathrm{C}$ ) was observed, followed by a slow decrease of similar magnitude (up to $20.3^{\circ} \mathrm{C}$ ) with a 94-hour lag. Later, this physical parameter remained relatively stable. Maximum EC and water temperature values respectively occurred 1 and $2 \mathrm{~h}$ before the first detection of PYR. In other words, the arrival of storm recharge from IP3 to the spring marks the beginning of the dilution effect.

\section{DISCUSSION}

Rock fracturing is one of the main genetic factors affecting the morphology, density and distribution of karst landforms (Ford \& Williams, 2007). The occurrence of dolines and other karst-related depressions aligned with the main set of fractures, in NE-SW and N-S directions (Fig. 7), confirms that the development of surface karst features in the Jarales area is governed by tectonics. This fact was already pointed out as the most likely origin of the depression that hosts the Jarales wetland (MMA, 2008). Likewise, the location and alignment of the inventoried swallow holes along the N-S axis in the northern half of the test site (Figs. $1 \& 7$ ), suggests that karst conduit development in the subsurface is significantly controlled by fracturing. In addition, the existence of such concentrated recharge features in the Amarga wetland (360 $\mathrm{m}$ a.s.1.), together with the NE-SW fault system between this wetland and Argamasilla Cave (347 m a.s.1.; IP1 in Figs. $1 \& 7$ ), may indicate that the two sites are connected through a preferential groundwater pathway. It has been suggested that under extremely high flow conditions, waters entering the Amarga swallow hole are directed toward the Lower Anzur Spring (MMA, 2008). However, this hydrogeological connection has not yet been proved, and therefore, groundwater flow towards the Genil River cannot be discarded. In any case, fracturing that affects massive gypsum blocks as well as the polygenic gypsiferous breccia (Figs. 4A \& B, respectively) predetermines the genesis and development of karstification, as revealed by a recent speleological survey carried out in Argamasilla Cave (Aljama-Martínez, 2016).

Additionally, the altitudinal contrast existing between the evaporitic karst plateau and its surrounding areas (25-50 $\mathrm{m}$ to the $\mathrm{N}$ and up to $150 \mathrm{~m}$ to the $\mathrm{S}$ ) could be related to halokinetic processes. Diapirism has been described in other CSC outcrops and its influence on karst development has been confirmed (Calaforra \& Pulido-Bosch, 1999). Hence, if the ground elevation of the study area were linked to halokinesis, it would also have affected the karst evolution, at both surface and subsurface. This assumption cannot be considered conclusive however, as further research is needed.

The dome morphology of the land surface also determines the hydrogeological characteristics of the study area (Andreo et al., 2016). Groundwater flows in a radial and divergent way, from the highest altitudes of the area to its borders, preferentially northwards, to the Anzur River. The location of the karst sinkholes used for the tracing experiment is coherent with this interpretation of the groundwater flow systems organization. Moreover, the detection of PYR and URN in the water drained by the Lower Anzur Spring validates the hydrological connection between the northern sector of the evaporitic plateau (IP1 \& IP3; Fig. 1) and the main outlet of the system, while also revealing the active role of exokarstic forms in its recharge (Fig. 10). The lack of detection of SRB in the monitored points does not prove the disconnection between IP2 and the controlled points (Fig. 1), especially considering the geological-hydrological context where this tracer was used: a karst system developed within predominantly clayey-evaporitic lithologies. Smart \& Laidlaw (1977) reported up to $49 \%$ of SRB retention on suspended minerals, Magal et al. (2008) proved $100 \%$ sorption of this dye on clays and other minerals (quartz and calcite) when $\mathrm{Cl}^{-}$ exceeds $100 \mathrm{~g} / 1$, and several authors documented the decreasing tracer fluorescence intensity when salinity increases (Feuerstein \& Selleck, 1963; Smart \& Laidlaw, 1977; Magal et al., 2008). The latter statement is furthermore confirmed in the present study (Fig. 6). The predominant clayey lithology of the CSC, the high turbidity of waters sinking into the swallow holes during tracer injections (Fig. 5), and also of the spring waters during the control period $(>1,000$ NTU coinciding with the highest concentrations of PYR and URN), together with their high salinity, would support 
the lack of SRB detection in this field test. At the same time, the intermediate position of IP2 (between IP1 and IP3 and the main outlet) and the high development of karstification along the N-S direction (Figs 1 \& 7) point to a probable hydrogeological connection between IP2 and the system drained by the Lower Anzur spring (Fig. 10).

As with SRB, the capacity of PYR and URN to be absorbed by rock minerals increases with salinity (Fig. 6); yet in such cases the effectiveness of tracer detection is enhanced by salinity, contrary to SRB (Magal et al., 2008). Therefore, the low tracer concentrations and recovery rates obtained for PYR (9 $\mu \mathrm{g} / 1$ and 13\%) and, particularly, for URN (0.6 $\mu \mathrm{g} / 1$ and $0.9 \%$ ) in the Lower Anzur Spring (Tab. 1), are mostly due to the predominant physical processes (sorption, dispersion, retardation, etc.) and chemical reactions (matrix diffusion, cation-exchange, etc.) occurring within clayey materials (Smart \& Laidlaw, 1977; Kasnavia et al., 1999), rather than to a poor connection. The sum of such processes promotes the loss of tracer mass during its migration through the clayey fractures and conduit walls and, possibly because of the suspended particulate matter in groundwater. Additionally, the geological complexity of CSC materials and the high solubility of evaporite rock minerals provoke faster dissolution/ karstification processes, resulting in heterogeneous conduit morphologies (i.e., conduit narrowing at the beginning of Argamasilla Cave; Fig. 3). A complex conduit geometry may also favor the development of stagnant (dead) zones or lateral storage areas that induce larger tracer dispersivities, as deduced from the long-tailed BTCsrecorded (Fig. 9).

In any case, the URN breakthrough curve, and especially the one for PYR (Fig. 9) are typical of well-developed karstic drainage (primarily in the unsaturated zone), with relatively steep rising limbs and sustained recession in tracer concentrations. This highlights the existence of a preferential flowpath running S-N (Fig. 10). Furthermore, the maximum effective flow velocities estimated in the tracer test (Tab. 1), particularly in the case of PYR (192 $\mathrm{m} / \mathrm{h})$, are equivalent to those deduced from other field experiments performed in highly karstified carbonate areas in southern Spain (Mudarra et al., 2014; Barberá et al., 2017). The apparent discharged groundwater volumes are relatively high compared to other tracer test results obtained in different evaporitic settings (Tab. 3), except for the investigations described by Forti (1993), which correspond to enormous speleogenetic networks (Forti \& Sauro, 1996; Calaforra \& Pulido-Bosch, 2003) that are not comparable.
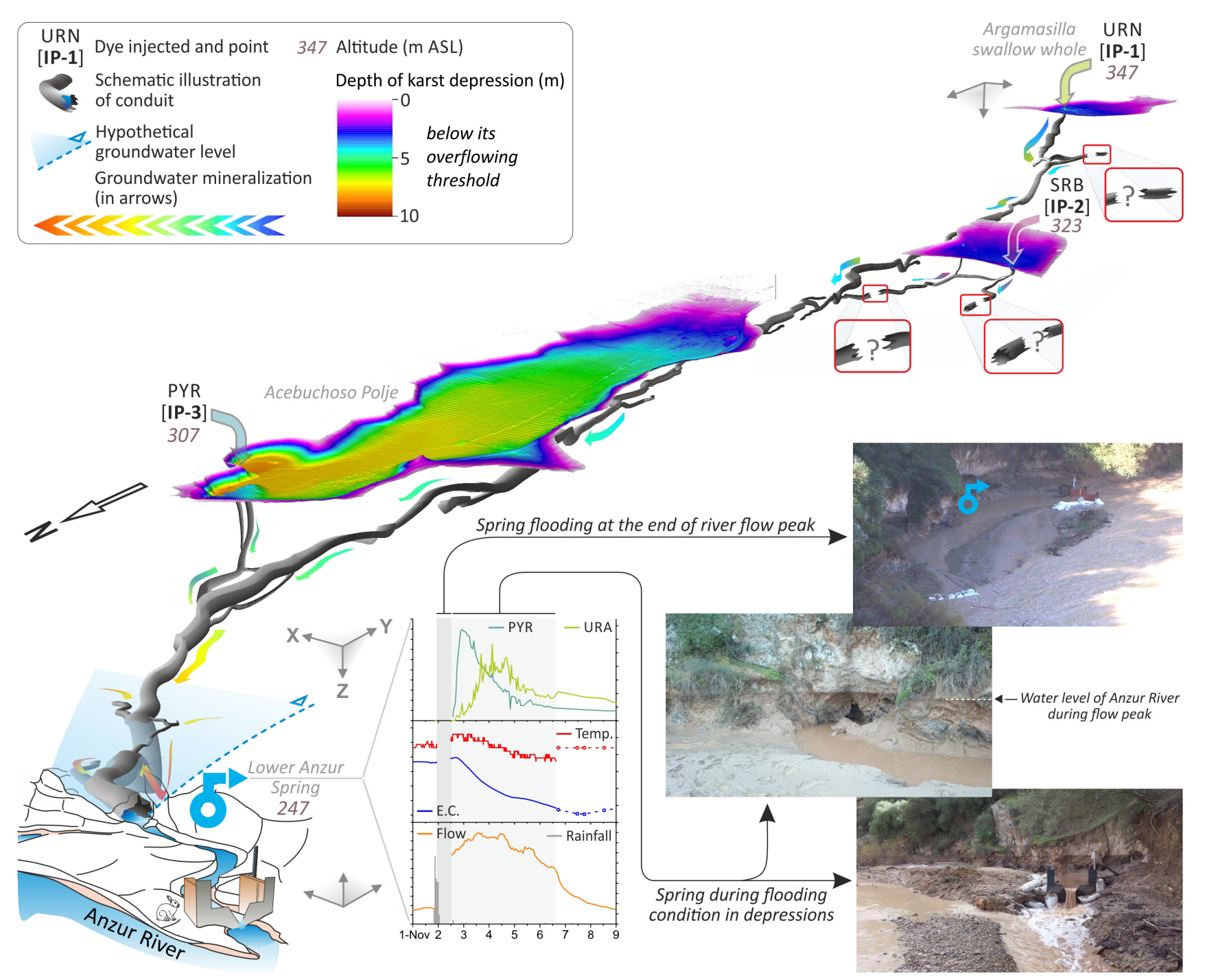

Fig. 10. Sketch of the hydrogeological functioning of the system drained by the Lower Anzur Spring, showing the contribution of closed depressions to the spring flow, deduced from tracer test results and monitoring of natural responses to an intense recharge pulse. 
Even though the distance between the IP1 swallow hole and the Lower Anzur spring is almost double that for IP3-Lower Anzur spring (Fig. 1), the first detection of URN occurred only $4 \mathrm{~h}$ after the arrival of PYR (Tab. 1). Still, mean effective flow velocities in both cases are of the same order (Tab. 1), according to the double lag time observed between each tracer injection and its respective peak tracer concentration in the outlet (54 vs 26 hours). Meanwhile, the maximum flow recorded during the field experiment (Fig. $9 \&$ Tab. 1) occurred a few hours after the URN concentration peak, giving rise to a decrease of both flow rate and tracer concentration. This suggests a strong relationship between infiltration occurring through IP1 and the hydrodynamic response of the outlet. Thus, IP1 could be considered as a relevant recharge point of the system. According to these results, a limited drainage capacity through a master karst conduit should be expected (Fig. 10), although it could be slightly higher at the initial segment (e.g., in Argamasilla Cave, Fig. 3) and presumably have less effective diameter in the remaining length (Hauns et al., 2001). Concentrated recharge coming from other endorheic areas located at intermediate positions (IP2 and IP3) would contribute to the complete saturation of the main conduit that hydraulically connects IP1 and the Lower Anzur spring, stemming the groundwater flow coming from IP1. As a consequence, the temporal reduction of drainage capacity would lead to the flooding of exokarst depressions if runoff generated over the endorheic areas exceeded their sinking capacities, as was observed during the test. After the spring drains most groundwater filling the principal conduit, the fraction of recharged water through IP1 would progressively increase. Subsequently, flooding conditions at the endorheic areas could be interrupted due to the drainage of groundwater stored in the conduits network (returning to vadose conditions) by the outlet, as is reflected in the hydrograph of the Lower Anzur Spring (Fig. 9). The constrained conduit morphology along the N-S flow path therefore has direct implications for the hydrogeological functioning of the evaporitic system, determining the natural response of the Lower Anzur Spring.
The estimates of groundwater volume draining the IP1-spring (URN) and IP3- spring (PYR) connections during the field test result in mean conduit diameters of $1.83 \mathrm{~m}$ and $1.49 \mathrm{~m}$, respectively (Tab. 2), which are slightly narrower than those estimated by Birk et al. (2004) for the Urenbrunnen gypsum karst spring (S Germany). These conduit sections resemble the surveyed segment of the Argamasilla Cave (Fig. 3). Yet, the difference between the computed volumes of the entire drainage network and the IP1-Lower Anzur spring connection (URN) is not consistent. If, despite uncertainties related to the lack of recorded data during the first hours of the test, the first estimated volume (whole conduit network) is taken to be correct, then the latter must be considered overestimated. The observed delay in the URN peak detection resulting from groundwater saturation of the conduits could be at the root of such anomalous volume computation. Considering the same mean diameter as for the IP3spring, the resulting volume calculated for the IP1spring conduit system is $9,938 \mathrm{~m}^{3}$, which could be coherent if recharge waters through both swallow holes quickly reached the master conduit (connecting IP1-spring; Fig. 10) almost simultaneously. In any case, the mean diameter of the latter conduit could not be greater than $1.49 \mathrm{~m}$, regardless of the plausible existence of further tributary inflows (e.g., underground pathway connecting IP2 to the master conduit). The total volume drained by the spring during the test as a response to the recharge pulse is estimated at $31,900 \mathrm{~m}^{3}$ (from the recharge pulse to the beginning of depletion). Accordingly, the volume of the water temporarily stored in the karst depressions can be estimated as the difference between the latter volume and that of the total karstic network, giving $27,600 \mathrm{~m}^{3}$. The monitoring of water levels into depressed areas, together with the accurate morphology data provided by the LiDAR DEM, would therefore allow one to calibrate this sort of estimate in further studies.

The increase in EC and water temperature recorded in the Lower Anzur spring, reaching maximum values 16 hours after the recharge pulse (Fig. 9), are attributable to a piston flow mechanism (Chiesi et al., 2010). The groundwater previously stored in the

Table 3. Comparative table of different dye tracer tests performed in diverse evaporitic settings and the obtained effective flow velocities.

\begin{tabular}{|c|c|c|c|}
\hline Reference & Location & Geological/hydrogeological setting & $\begin{array}{l}\text { Apparent flow } \\
\text { rates }(\mathrm{m} / \mathrm{h})\end{array}$ \\
\hline Forti (1993) & $\begin{array}{l}\text { Gypsum karst of Sorbas (Spain) } \\
\text { \& Emilia-Romagna (Italy) }\end{array}$ & $\begin{array}{c}\text { Barren exposed karst. Through flowing underground } \\
\text { streams }\end{array}$ & $360-5,400$ \\
\hline Klimchouk (1996) & $\begin{array}{c}\text { Jazovsky sulphur deposits } \\
\text { (Ukraine) }\end{array}$ & $\begin{array}{l}\text { Deep-seated karst setting. Borehole-borehole } \\
\text { connection }\end{array}$ & $17-104$ \\
\hline Klimchouk (1996) & Podolsky area (Ukraine) & $\begin{array}{l}\text { Entrenched gypsum karst overlying sandy-carbonate } \\
\text { aquifer. Ponor-spring connection }\end{array}$ & $12.5-21$ \\
\hline Birk et al. (2004) & $\begin{array}{l}\text { Urenbrunnen gypsum karst } \\
\text { spring (Germany) }\end{array}$ & Gypsum and marls layer aquifer & $31-77$ \\
\hline $\begin{array}{l}\text { Mancebo Piqueras } \\
\text { et al. (2012) }\end{array}$ & Caspe Dam (Spain) & Water seepage beneath clayey-evaporite deposits & $<1$ \\
\hline Bikshe et al. (2014) & Upmale hillock plain (Latvia) & $\begin{array}{c}\text { Gypsum and carbonaceous rocks covered } \\
\text { by Quaternary low to high permeable deposits. } \\
\text { Complex structure }\end{array}$ & $21-42$ \\
\hline Strasser et al. (2016) & $\begin{array}{l}\text { Weir lock Hessigheim, Neckar } \\
\text { River (Germany) }\end{array}$ & Deep confined clayey-anhydrite aquifer & $0.07-0.3$ \\
\hline This research & Lower Anzur Spring (Spain) & Clayey-evaporite mélange with local karstification & $70-192$ \\
\hline
\end{tabular}


saturated conduit (where water with higher salinity and warmer temperature is stored) is pushed out to the discharge point (Fig. 10), as a result of the transfer of the water pressure from the intense and concentrated recharge episode (Gil-Márquez et al., $2017 \mathrm{~b})$. After the drainage of stored groundwater (Fig. 8), a mixture of recently infiltrated runoff through the swallow holes (i.e., in which dye tracer dissolved) and old groundwater arrives to the spring, leading to the progressive dilution and cooling of spring water. The lowest EC values $(120.6 \mathrm{mS} / \mathrm{cm}$; chemograph in Fig. 8) were recorded after $120 \mathrm{~h}$, approximately 1 day after the swallow holes fully emptied the flooded endorheic depressions, and it started to rise from that moment onward (Fig. 8). This fact, together with the marked fall in the spring flow observed between 6 and 7 November 2015 (Fig. 8), suggests that once the karst depressions are fully emptied (i.e., after rapid infiltration stopped), the spring depletion begins and physico-chemical parameters in groundwater progressively tend to reach the pre-event values. This finding underlines the influence of the limited drainage capacity of karst depressions and conduits on the Lower Anzur Spring hydrodynamics. During the flooding of the swallow holes, the spring hydrograph undergoes smooth variations in the range of higher flow (phreatic conduit), tracing a flattened discharge evolution that lasted for several days (Fig. 9). The slow water table lowering at the endorheic depressions hosting swallow holes would also produce a subtle depletion in spring discharge and, hence an inertial response. However, when the water inflows through the swallow holes are depleted, the spring flow diminishes more rapidly (epiphreatic conduit) and the amount of recently recharged water that is drained by the spring gradually decreases. The EC positive trend observed (from 9 November; Fig. 9) could be due to either a greater water-rock interaction, as a result of the gradual groundwater flow reduction, or to a greater participation of diffuse groundwater flows in the karst drainage, with higher residence time and mineralization, or to both processes simultaneously.

\section{CONCLUSIONS}

The geomorphological study of an evaporitic plateau using LiDAR airborne data and GIS-based algorithms for the automatic detection of closed depressions, and the analysis of spring impulsional responses and tracer migration along a defined karst underground flowpath, have led to a deeper understanding of (exo- and endo-) karst development and the groundwater flow mechanisms of an evaporitic karst area in S Spain.

The geo-processing of digital elevation models made it possible to automatically recognize numerous karst-related depressions, as well as determine their depth and preferential alignments. Landform analysis suggests that karst development, at both surface and subsurface, is linked to the regional fault systems, and in particular to fracture density and orientation.

The multitracer test performed in the Jarales area helped to define the main karst hydrogeological connections between closed exokarst areas and the Lower Anzur Spring, to roughly estimate the conduit network geometry, and to advance in knowledge of the system's functioning. Analysis of the natural responses of the outlet, together with the dye tracer results, revealed its clearly karstic behavior, with estimated effective flow velocities similar to others described in carbonate karst areas and slightly higher than those documented in European evaporite karst setttings. Furtermore, a very substantial contribution of the concentrated recharge through swallow holes to the spring flow and its influence on the spring hydrodynamics is inferred. The methodological procedure for tracer concentration determination was specifically modified due to the high salinity of the groundwater, and some key issues related to the clayey nature of the bedrock (e.g., turbidity, dye sorption) have been discussed, in view of their utility/ replicability in similar applications worldwide.

The analysis of readily available spatial information in conjunction with the application of conclusive tracing techniques (using both environmental and artificial tracers) has proven useful as a proxy to attain a global knowledge of the genesis, evolution and hydrogeological functioning of an evaporitic karst area. The combined approach used in this study could be adapted to other evaporitic systems worldwide, whether at local or regional scale, given that is application is technically feasible and economically affordable. Advances in evaporitic karst hydrogeology are essential for the proper management of related ecosystems (i.e., wetland areas), for dealing with related geo-hazards appropriately, and for mitigating the environmental impact of highly mineralized waters downstream.

\section{ACKNOWLEDGEMENTS}

This work is a contribution to the Excellence Projects RNM-8087-11 and RNM-6895R-10 of the Autonomous Government of Andalusia (Spain), and to the research group RNM-308 of the Junta de Andalucia. The authors greatly thank Muzaffar Matchanov and Marta Rojas Torreño and Carmen Yeste Oliva for their help in gauging station maintenance and sampling tasks, respectively. They are very grateful to Abén Aljama Martinez and his colleagues (speleological group G40), who provided the valuable information and pictures about Argamasilla Cave exploration. The authors also thank three anonymous reviewers for their constructive criticisms that contributed to improving the original version of the manuscript. Suggestions for improvements by Associate Editor Jo De Waele, we much appreciated.

\section{REFERENCES}

Acero P., Auqué L., Galve J.P., Gutiérrez F., Carbonel D., Gimeno M.J., Yechieli Y., Asta M.P. \& Gómez J.B., 2015 - Evaluation of geochemical and hydrogeological processes by geochemical modeling in an area affected by evaporite karstification. Journal of Hydrology, 529: 1874-1889.

https://doi.org/10.1016/j.jhydrol.2015.07.028 
Alexander S., 2005 - Spectral deconvolution and quantification of natural organic material and fluorescent tracer dyes. In: Beck B.F. (Ed.), Sinkholes and the engineering and environmental impacts of karst: Proceedings of the tenth multidisciplinary conference, September 24-28, 2005, San Antonio, Texas, p 1-8. https://doi.org/10.1061/40796(177)47

Aljama Martínez A., 2016 - Sumidero de Argamasilla. Informe de cavidad. Unpublished report. Archive of Grupo Espeleológico G40. Córdoba, 23 p.

Anders N.S., Seijmonsbergen A.C. \& Bouten W., 2011 - Segmentation optimization and stratified object-based analysis for semi-automated geomorphological mapping. Remote Sensing of Environment, 115 (12): 2976-2985. https://doi.org/10.1016/j.rse.2011.05.007

Andreo B., Vías J., Durán J.J., Jiménez P., López-Geta J.A. \& Carrasco F., 2008 - Methodology for groundwater recharge assessment in carbonate aquifers: Application to pilot sites in southern Spain. Hydrogeology Journal, 16 (5): 911-925.

https://doi.org/10.1007/s10040-008-0274-5

Andreo B., Gil-Márquez J.M., Mudarra M., Linares L., \& Carrasco F., 2016 - Hypothesis on the hydrogeological context of wetland areas and springs related to evaporitic karst aquifers (Málaga, Córdoba and Jaén provinces, Southern Spain). Environmental Earth Sciences, 75 (9): 1-19.

https://doi.org/10.1007/s12665-016-5545-1

Barberá A., Mudarra M., Andreo B. \& De la Torre B., 2017 - Regional-scale analysis of karst underground flow deduced from tracing experiments: examples from carbonate aquifers in Malaga province, southern Spain. Hydrogeology Journal, accepted.

Bikshe J., Babre A., Delina A. \& Popovs K., 2014 Analysis of multicomopnent groundwater flow in karst aquifer by CFC, tritium, tracer test and modelling, case study at Skaistkalnes vicinity, Latvia. In: EGU General Assembly Conference Abstracts. p. 15493.

Birk S., Liedl, R. \& Sauter M., 2004 - Identification of localized recharge and conduit flow by combined analysis of hydraulic and physico-chemical spring responses (Urenbrunnen, SW-Germany). Journal of Hydrology, 286 (1-4): 179-193.

https://doi.org/10.1016/j.jhydrol.2003.09.007

Calaforra J.M., \& Pulido-Bosch A., 1999 - Gypsum karst features as evidence of diapiric processes in the Betic Cordillera, Southern Spain. Geomorphology, 29 (3-4): 251-264. https://doi.org/10.1016/S0169-555X(99)00019-7

Calaforra J.M. \& Pulido-Bosch A., 2003 - Evolution of the gypsum karst of Sorbas (SE Spain). Geomorphology 50 (1-3): 173-180.

https://doi.org/10.1016/S0169-555X(02)00213-1

Calaforra J.M., Forti P. \& Fernandez-Cortes A., 2008 - Speleothems in gypsum caves and their paleoclimatological significance. Environmental Geology, 53 (5): 1099-1105.

https://doi.org/10.1007/s00254-007-0737-3

Chiesi M., De Waele J. \& Forti P., 2010 - Origin and evolution of a salty gypsum/ anhydrite karst spring: The case of Poiano (Northern Apennines, Italy). Hydrogeology Journal, 18 (5): 1111-1124.

https://doi.org/10.1007/s10040-010-0576-2

CMA, 2005 - Definición del contexto hidrogeológico de humedales andaluces. Vol. III. Unpublished report. Grupo de Hidrogeología de la Universidad de Málaga y Consejería de Medio Ambiente de la Junta de Andalucía, Sevilla, 135 p.
Divar J., Roldán F.J. \& Molina J.M., 1988 - Geological map of Spain, Benameji sheet. Scale 1:50.000, Instituto Geológico y Minero de España, Madrid.

Durán J.J. \& Burillo F.J., 1985 - Triassic gypsum karst of the Loma del Yesar (Archidona, Malaga; Southern Spain). La Grotte d'Italia, 4 (4): 237-246.

EC, 1995 - Hydrogeological aspects of groundwater protection in karstic areas. European Commission, Report EUR 16547 EN, 15 p.

Feuerstein, D.L. \& Selleck R.E., 1963 - Fluorescent tracers for dispersion measurements. Journal of Sanitary Engineering Division - American Society of Civil Engineers, 89 (4): 1-22.

Fidelibus M. D., Gutiérrez F. \& Spilotro G., 2011 - Humaninduced hydrogeological changes and sinkholes in the coastal gypsum karst of Lesina Marina area (Foggia Province, Italy). Engineering Geology, 118 (1-2): 1-19. https://doi.org/10.1016/j.enggeo.2010.12.003

Ford D.C. \& Williams P.W., 2007 - Karst hydrogeology and geomorphology. Wiley, Chichester, $562 \mathrm{p}$. https://doi.org/10.1002/9781118684986

Forti P., 1993 - Karst evolution and water circulation in gypsum formations. Proceedings of the International Symposium on Water Research in Karst with Special Emphasis in Arid and Semi-Arid Zones, 23-26 Oct. 1993, Shiraz, Iran, p. 791-801.

Forti P., 2004 - Gypsum karst. In: Goudie A.S. (Ed.), Encyclopedia of geomorphology. Routledge, Taylor \& Francis Group, London, p. 509-511.

Galve J.P., Gutiérrez F., Lucha P., Bonachea J., Remondo J., Cendrero A., Gutiérrez M., Gimeno M.J., Pardo G. \& Sánchez J.A., 2009 - Swallow holes in the salt-bearing evaporite karst of the Ebro River valley upstream of Zaragoza city (NE Spain): geomorphological mapping and analysis as a basis for risk management. Geomorphology 108 (3-4): 145-158.

https://doi.org/10.1016/j.geomorph.2008.12.018

Gil-Márquez J.M., Mudarra M., Andreo, B., Linares L., Carrasco F. \& Benavente J., 2016 - Hydrogeological characterization of the Salinas- Los Hoyos evaporitic karst (Málaga Province, S Spain) using topographic, hydrodynamic, hydrochemical and isotopic methods. Acta Carsologica, 45 (2): 147-160.

https://doi.org/10.3986/ac.v45i2.4504

Gil-Márquez J.M., Barberá J.A., Andreo B. \& Mudarra M., 2017a - Hydrological and geochemical processes constraining groundwater salinity in wetland areas related to evaporitic (karst) systems. A case study from Southern Spain. Journal of Hydrology, 544: 358-554. https://doi.org/10.1016/j.jhydrol.2016.11.062

Gil-Márquez J.M., Mudarra M. \& Andreo B., 2017b - Analysis of Natural Response and Hydrochemical Data by Statistical Approaches to Characterize the Hydrogeological Functioning of a Highly Karstified Evaporitic System in South Spain. In: Renard B. \& Bertrand C. (Eds.), Advances in karst sciences. Eurokarst 2016, Neuchâtel, Springer, p. 335-343. https://doi.org/10.1007/978-3-319-45465-8_32

Goldscheider N. \& Drew D. (Eds.), 2007 - Methods in karst hydrogeology. Taylor \& Francis, London, 264 p.

Goldscheider E., Meiman J., Pronk M. \& Smart C., 2008 - Tracer Tests in karst hydrogeology and speleology. International Journal of Speleology, 37 (1): 27-40. https://doi.org/10.5038/1827-806X.37.1.3

González Ríos M.J., López Chicano M. \& Moreno Rosa A., 1994 - Grandes cavidades de la provincia de Córdoba. Espeleotemas, 4: 31-42. 
Goudie A.S., 2004 - Salt related landforms. In: Goudie A.S. (Ed.), Encyclopedia of geomorphology. Routledge, Taylor \& Francis Group, London, p. 893-894.

Grillot J.C., 1979 - Structure des système aquifères en milieu fissuré. Contribution méthodologuique à cette connaissance. Unpublished $\mathrm{PhD}$ thesis, U.S.T.L. Montpellier (France), $212 \mathrm{p}$.

Gutiérrez F., Calaforra J.M., Cardona F., Ortí F., Durán J.J. \& Garay P., 2008 - Geological and environmental implications of the evaporite karst in Spain. Environmental Geology, 53 (5): 951-965.

https://doi.org/10.1007/s00254-007-0721-y

Gutiérrez F., Parise M., De Waele J. \& Jourde H., 2014 - A review on natural and human-induced geohazards and impacts in karst. Earth Science Reviews 138: 61-88. https://doi.org/10.1016/j.earscirev.2014.08.002

Hauns M., Jeannin P.Y. \& Atteia O., 2001 - Dispersion, retardation and scale effect in tracer breakthrough curves in karst conduits. Journal of Hydrology, 241 (3-4): 177-193.

https://doi.org/10.1016/S0022-1694(00)00366-8

IGN - Instituto Geográfico Nacional. Ministerio de Fomento, Gobierno de España [accesed: November 17, 2016]. http://centrodedescargas.cnig.es/

Jeannin P.Y., Groves C. \& Häuselmann P., 2007 Speleological investigations. In: Goldscheider N. \& Drew D.P. (Eds.), Methods in karst hydrogeology. Taylor and Francis / Balkema, London, p 93-121.

Johnson K.S., 1997 - Evaporite karst in the United States. Carbonates and Evaporites, 12 (1): 2-14.

https://doi.org/10.1007/BF03175797

Kasnavia T., Vude D. \& Sabatini D.A., 1999 - Fluorescent dye and media properties affecting sorption and tracer selection. Ground Water, 37 (3): 376-381.

https://doi.org/10.1111/j.1745-6584.1999.tb01114.x

Käss W., 1998 - Tracing technique in geohydrology. Balkema, Rotterdam, 600 p.

Klimchouk A., 1996 - Hydrogeology of gypsum formation. International Journal of Speleology, 25 (3-4): 83-89. https://doi.org/10.5038/1827-806X.25.3.6

Klimchouk A., Forti P. \& Cooper A., 1996 - Gypsum karst of the world: a brief overview. International Journal of Speleology, 25 (3-4): 159-181.

https://doi.org/10.5038/1827-806X.25.3.12

Klimchouk A.B. \& Aksem S.D., 2005 - Hydrochemistry and solution rates in gypsum karst: Case study from the Western Ukraine. Environmental Geology, 48 (3): 307-319. https://doi.org/10.1007/s00254-005-1277-3

Lauber U. \& Goldscheider N., 2014 - Use of artificial and natural tracers to assess groundwater transittime distribution and flow systems in a high-alpine karst system (Wetterstein Mountains, Germany). Hydrogeology Journal, 22 (8): 1807-1824. https://doi.org/10.1007/s10040-014-1173-6

Liguori V., Manno G., \& Mortellaro D., 2008 - Evaporite karst in Sicily. Environmental Geology, 53 (5): 975-980. https://doi.org/10.1007/s00254-007-0723-9

Luhmann A.J., Covington M.D., Alexander S.C., Chai S.Y., Schwartz B.F., Groten J.T. \& Alexander E.C., 2012 - Comparing conservative and nonconservative tracers in karst and using them to estimate flow path geometry. Journal of Hydrology, 448-449: 201-211. https://doi.org/10.1016/j.jhydrol.2012.04.044

Magal E., Weisbrod N., Yakirevich A. \& Yechieli Y., 2008 - The use of fluorescent dyes as tracers in highly saline groundwater. Journal of Hydrology, 358 (1-2): 124-133. https://doi.org/10.1016/j.jhydrol.2008.05.035
Mancebo Piqueras J.A., Sanz Pérez E. \& Menéndez-Pidal I., 2012 - Water seepage beneath dams on soluble evaporite deposits: A laboratory and field study (Caspe Dam, Spain). Bulletin of Engineering Geology and the Environment, 71: 201-213.

https://doi.org/10.1007/s10064-011-0379-2

Martín-Serrano A., 1986 - Geological map of Spain, Benameji sheet. Scale 1:50.000, Instituto Geológico y Minero de España, Madrid.

MMA, 2008 - Definición del contexto hidrogeológico de humedales de la campiña andaluza centra. Vol. II. Unpublished report. Universidad Pablo de Olavida y Confederación Hidrográfica del Guadalquivir, Ministerio de Medio Ambiente, 335 p.

Mora Luque J.A., 2006 - Cuevas y simas de la provincia de Córdoba. Estudios de medio ambiente provincial. Diputación de Córdoba, 114 p.

Mudarra M., Andreo B., Marín A.I., Vadillo I. \& Barberá, J.A., 2014 - Combined use of natural and artificial tracers to determine the hydrogeological functioning of a karst aquifer: the Villanueva del Rosario system (Andalusia, southern Spain). Hydrogeology Journal, 22 (5): 1027-1039.

https://doi.org/10.1007/s10040-014-1117-1

Mudarra M., Gil-Márquez J.M., Argamasilla M., Andreo B. \& Carrasco F., 2016 - Identificación de formas de relieve negativo a partir de datos de vuelo LiDAR. Aplicación al karst evaporítico de Gobantes (Málaga). In: Durán J.J., Montes Santiago M., Robador A. \& Salazar A. (Eds.), Comprendiendo el relieve: del pasado al futuro. Instituto Geológico y Minero, Madrid, p. 647-654.

Pardo-Igúzquiza E., Durán J.J. \& Dowd P.A., 2013 Automatic detection and delineation of karst terrain depressions and its application in geomorphological mapping and morphometric analysis. Acta Carsologica, 42 (1): 17-24.

https://doi.org/10.3986/ac.v42i1.637

Parise M., Qiriazi P. \& Sala S., 2008 - Evaporite karst of Albania: Main features and cases of environmental degradation. Environmental Geology, 53 (5): 967-974. https://doi.org/10.1007/s00254-007-0722-x

Pérez-López A. \& Sanz de Galdeano C., 1994 - Tectónica de los materiales triásicos del sector central de la Zona Subbética (Cordillera Bética). Revista de la Sociedad Geológica de España, 7 (1-2): 141-153.

PNOA - Plan Nacional de Ortofotografía Aérea. PNOA LiDAR. Instituto Geográfico Nacional, Gobierno de España [accesed: December 23, 2016]. http://pnoa.ign.es/presentacion

Pulido-Bosch A. \& Calaforra J.M., 1993 - The gypsum karst aquifer of Sorbas (Almeria). In: Pulido-Bosch A. (Ed.), Some Spanish karstic aquifers. University of Granada, p. 225-241.

Rodríguez-Rodríguez M., Moral F., Benavente J. \& Beltrán M., 2010 - Developing hydrological indices in semi-arid playa-lakes by analyzing their main morphometric, climatic and hydrochemical characteristics. Journal of Arid Environments, 74 (11): 1478-1486.

https://doi.org/10.1016/j.jaridenv.2010.03.018

Sánchez D., Carrasco F. \& Andreo B., 2009 - Proposed methodology to delineate bodies of groundwater according to the European water framework directive. Application in a pilot Mediterranean river basin (Málaga, Spain). Journal of Environmental Management, 90 (3): 1523-1533. https://doi.org/10.1016/j.jenvman.2008.11.001 
Siart C., Bubenzer O. \& Eitel B., 2009 - Combining digital elevation data (SRTM/ASTER), high resolution satellite imagery (Quickbird) and GIS for geomorphological mapping: A multi-component case study on Mediterranean karst in Central Crete. Geomorphology, 112 (1-2): 106-121. https://doi.org/10.1016/j.geomorph.2009.05.010

Smart P.L. \& Laidlaw I.M.S., 1977 - An evaluation of some fluorescent dyes for water tracing. Water Resource Research, 13 (1): 15-33. https://doi.org/10.1029/WR013i001p00015

Strasser D., Montenegro H., Blechschmidt L., Liesch T. \& Goldscheider N., 2016 - Multi-tracer approach to characterize hydraulically induced sulfate rock dissolution processes below a weir lock. Journal of Applied Water Engineering and Research, 1-16. https://doi.org/10.1080/23249676.2016.1172992

Tóth J., 1963 - A theoretical analysis of groundwater flow in small drainage basins. Journal of Geografical Research, 68: 4795-4812.

https://doi.org/10.1029/jz068i016p04795

Tóth J., 1970 - A conceptual model of the groundwater regime and the hydrogeologic environment. Journal of Hydrology, 10 (1): 64-176.

https://doi.org/10.1016/0022-1694(70)90186-1
Vera J.A. \& Martín-Algarra A., 2004 - Cordillera Bética. In: Vera J.A. (Ed.), Geología de España. IGME-Sociedad Geológica de España, p. 345-464.

Vojtechovska A., Bruthans J. \& Krejca F., 2010 Comparison of conduit volumes obtained from direct measurements and artificial tracer tests. Journal of Cave and Karst Studies, 72 (3): 156-160. https://doi.org/10.4311/jcks2009es0095

Warren J.K., 2016 - Salt dissolution and pointers to vanished evaporites: Karst, breccia, nodules and cement. In: Warren J.K. (Ed.), Evaporites: a geological compendium. Springer, Cham, p. 613-762. https://doi.org/10.1007/978-3-319-13512-0_7

Williams P., 2008 - World heritage caves and karst. Gland, Switzerland: IUCN, 57 p.

White W.B., 1988 - Geomorphology and hydrology of karst terrains. Oxford University Press, New York, 464 p.

Yechieli Y., Abelson M. \& Baer G., 2016 - Sinkhole formation and subsidence along the Dead Sea coast, Israel. Hydrogeology Journal, 24: 601-612. https://doi.org/10.1007/s10040-015-1338-y

Zhou G., Song C., Simmers J. \& Cheng P., 2004 - Urban $3 D$ GIS from LiDAR and digital aerial images. Computers and Geosciences, 30 (4): 345-353. https://doi.org/10.1016/j.cageo.2003.08.012 